\title{
Sullivania a new genus of Palaeogene coccoliths
}

\author{
O. VAROL \\ Varol Research \\ PO Box 714, Conwy, \\ Gwynedd, LL32 8QH, U.K.
}

\begin{abstract}
It is shown that the genus Chiasmolithus as currently understood comprises two discrete lineages. It is proposed that these should be formally recognised as separate genera. A new genus, Sullivania, is described and ten new combinations: S. californica, S. consueta, S. danica, S. edwardsii, S. gigas, S. inconspicua, S. minima, S. nitida, S. titus and Cruciplacolithus oulchyensis are introduced. The speculative evolution in the genera Cruciplacolithus, Sullivania and Chiasmolithus is discussed and illustrated. J. Micropalaeontol., 11(2), 141-150, December 1992.
\end{abstract}

\section{INTRODUCTION}

Until now the genus Chiasmolithus has been used for Palaeogene placoliths with a diagonal cross of $\mathrm{X}$ or $\mathrm{H}$ shape, regardless of the structure of the arm or the number of tube cycles. Detailed studies on the lineages in and structure of Chiasmolithus were presented by Gartner (1970), Romein (1979), Perch-Nielsen (1985) and van Heck \& Prins (1987). Gartner (1970) and Romein (1979) distinguished two groups of Chiasmolithus based on the structure of the diagonal cross. Perch-Nielsen (1985) also distinguished two groups of Chiasmolithus, but based on the extent of elements surrounding the central area distally; Group A (elements do not reach crest or just reach crest), which included the forms here distinguished as Sullivania and Group B (build the crest), here retained by Chiasmolithus.

In this study, only the species with two distally exposed tube cycles, a central mesh and a complex diagonal cross are retained in the genus Chiasmolithus (Fig. 1; Gartner, 1970, fig.3). These criteria are consistent with the characteristics of the type species Chiasmolithus oamaruensis.

The taxa with a single distally exposed tube cycle and a diagonal cross of which the arms are constructed by transverse elements have been assigned to the new genus Sullivania (Fig. 1; Gartner, 1970, fig. 5). There is no central mesh in the opening between the arms of the central cross. These criteria are consistent with the characteristics of the type species Sullivania consueta.

The various species of Chiasmolithus and Sullizanin are used as markers throughout the Palaeogene, but with the introduction of further species, the potential exists for a more detailed biostratigraphy than currently available. In the present study the zonation schemes of Martini (1971) and Varol (1989) are applied (Fig, 2).

\section{LINEAGES}

The genera Cruciplacolithus, Sullivania and Chiasmolithus constitute a distinctive sub-group within the Palaeogene Coccolithaceae. Lineages within this group have been discussed by Gartner (1970), Romein (1979), Perch-Nielsen (1985), and van Heck \& Prins (1987). However, there has been no comprehensive overview for the entire Palaeogene, and new information and the description of additional species means that the previous schemes need revision. Figure 2 presents a revised analysis of the lineages. It is based on the published work as tested and supplemented by the present author's observations. The notes below concentrate on points of disagreement.

\section{SPECULATIONS ON THE LINEAGES IN SULLIVANIA}

Sullivania edwardsii is the oldest known species of the genus and developed from Cruciplacolithus intermedius in Zone NP2 (NTp3A) by rotation of the central cross. Sullivania danica developed from S. edwardsii at the base of Zone NP3 (NTp3B) by rotation and narrowing of the angle of the central cross. The longer arm became curved and slightly dislocated at the centre whilst the short arm remained straight. Within Zone NP3 (NTp5), S. inconspicun developed from S. danica by further rotation of the diagonal cross until the gently curved arms became equal in length and by the diagonal cross becoming only weakly birefringent under cross-polarised light. This part of the evolutionary lineage was suggested by van Heck \& Prins (1987) and the present author agrees with them.

In Zone NP5 (NTp9) S. consuleta developed from $S$. inconspicua by an increase in size and by the diagonal cross becoming more distinct. Sullivania californica developed from S. consueta by becoming larger within Zone NP9 (NTp20). In Zone NP12, S. minima also developed from S. consuet $n$ by slight rotation of its diagonal cross. The arms became straight and unequal in length and the short arm became slightly dislocated with respect to the long one. Sulliznnia minima developed into Sullivania titus by the curving of the long arm in Zone NP12, which in turn developed into $S$. nitidn by the development of 'feet' at the end of the diagonal cross. Within Zone NP15, S. gigas developed from S. minima by enlargement of its shields and reduction of its central area.

\section{SPECULATIONS ON THE LINEAGES IN CHIASMOLITHUS}

Chiasmolithus edentulus is the oldest known species of the genus. The view that Ch. edentulus (partly Chinsmolithus bidens of others) evolved from $S$. danica as suggested by Gartner 


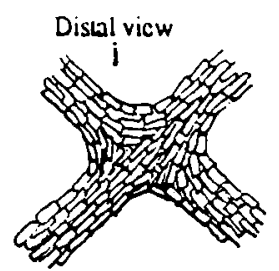

Diugonal cross in Chiasmolithus

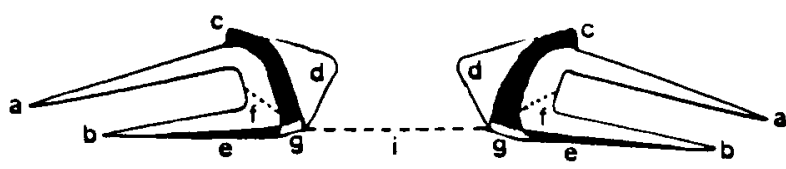

Cross sccuion of Chiasmolithus
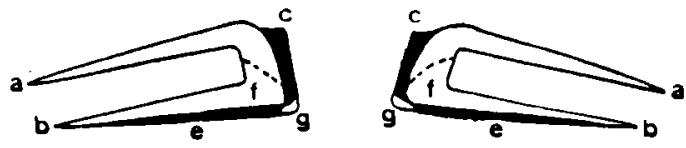

Cross sccion of Sullivanis

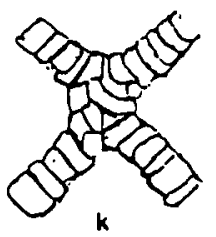

Distal/proximal vicws of diagonal cross in Sulliwania

Fig. 1. Cross sections of Sullivania and Chiasmolithus and structure of their diagonal crosses (for meaning of annotations see Terminology, Plate 1).

(1970), Romein (1979) and Perch-Nielsen (1985) is not shared here; instead it is believed to be somehow related to Ericsonia sparsa and Cruciplacolithus? Sp.1 (sensu Perch-Nielsen, 1971; Pl.1, Fig.9). Although the genera Sullivania and Chiasmolithus are superficially similar, there are major detailed structural differences, which are discussed here. There is considered to be insufficient time between the evolutionary appearances of S. danica and Ch. edentulus to accommodate the obvious major structural changes. The most important difference is the number of tube cycles. In Chiasmolithus edentulus the distally exposed tube cycle is double, whilst in Sullivania danica a single distally exposed tube cycle is present (Fig. 1). Other differences are noted in the central area; $C h$. edentulus has a diagonal cross with complex structure and a central mesh, whereas $S$. danica has a simply constructed central cross and lacks a central mesh. In particular, the development of the extra tube cycle in such a very short time span seems unlikely.

Moreover, the different opinions on the lineages of Chiasmolithus and Sullivania are also the result of the varying concepts of S. danica. In the present study, the lectotype designated by van Heck \& Perch-Nielsen (1987) is followed. Their description and figures clearly indicate that $S$. danica s.s. has a single, distally exposed, tube cycle and a simple diagonal cross. $C h$. danicus of Gartner (1970), Romein (1979), PerchNielsen (1985) and van Heck \& Prins (1987) includes S. danica s.s. and so-called 'intermediate' or 'late' forms which have two, distally exposed, tube cycles and a complex diagonal cross (divided into two halves under cross-polarised light). These latter forms are variations of Ch.edentulus and are not considered to be related to $S$. danica. The above authors, therefore, assigned these so-called 'intermediate' or 'late' forms to their Ch. danicus. The application of a wider species concept, subsequently led these authors to suggest different lineages in Chiasmolithus and Sullivania than those presented here.

Ch. edentulus gave rise to nine species in which constitute a coherent Palaeogene lineage of well documented species, characterised mainly by central area features.

In Ch. edentulus which has its first occurrence in Zone NP4 (NTp7B), one arm is straight whilst the other is slightly curved and is dislocated in the centre along the straight arm. Ch. bidens developed from $\mathrm{Ch}$. edentulus in Zone NP6 (NTp10C) by the growth of two teeth protruding from the side of the inner tube cycle. Chiasmolithus grandis developed from Ch. bidens in Zone NP11 by the growth of two more teeth at the poles in addition to those on the sides and by an increase in the curvature of both arms. In Zone NP10 Chiasmolithus solitus developed from Ch.edentulus by increased curvature of the longer arm and its rotation towards the long axis, becoming almost parallel to it. Both arms of the cross also became more delicate. Chiasmolithus eograndis also developed from $\mathrm{Ch}$. edentulus in Zone NP10, by rotation of both arms and merging of their central part to form an oblique common arm giving an overall ' $\mathrm{H}$ ' shape to the cross. One of the arms is usually more curved than the other. Chiasmolithus expansus developed from $\mathrm{Ch}$. eograndis by increased curvature of the arms. The arms are equal in length and symmetrical. The angles between them are greater along the short axis. Chiasmolithus medius developed from $\mathrm{Ch}$. eograndis in Zone NP15 by reduction of the curvature of one of the arms such that both arms form a short longitudinal common arm in the centre. Both arms are equal and symmetrical. Chiasmolithus modestus developed from Ch. medius in Zone NP16 by straightening and slight rotation of the arms until they made a right angle. Chiasmolithus oamaruensis developed from Ch. modestus at the base of Zone NP18 by further rotation of the arms until they made a small angle along the short axis of the ellipse. 


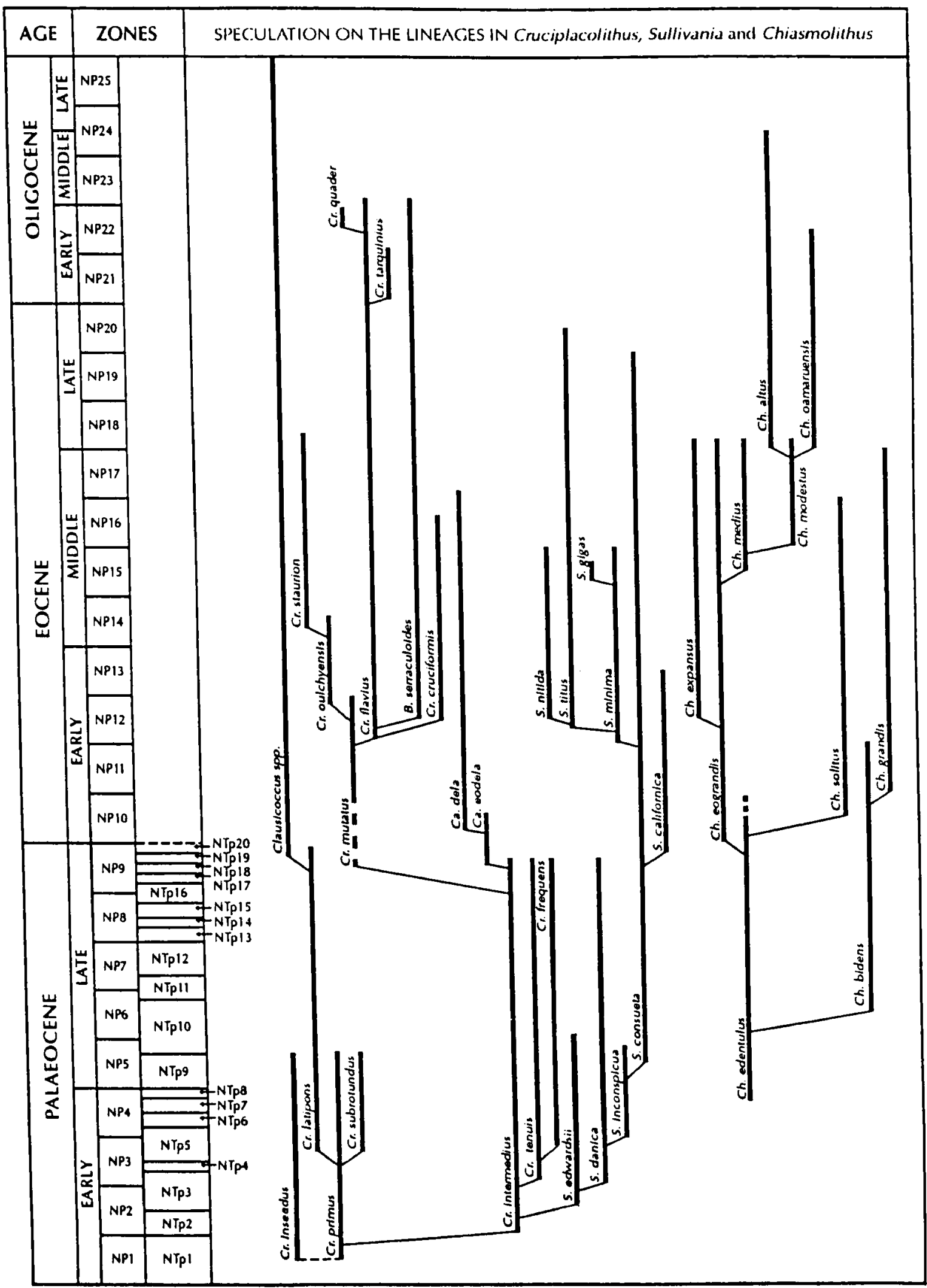

Fig. 2 Speculations on the lineages in Cruciplacolithus, Sullivania and Chinsmolithus (NP Zones after Martini, 1971, NTp Zones after Varol, 1989). Abbreviations: NP - Nannofossils, Palaeogene; NTp - Nannofossils Tertiary, Palaeocene; $\mathrm{Cr}$-Cruciplacolithus; Ch - Chinsmolithus; $S$ - Sullizania; $B$ - Bramletteius; Ca-Campylosphaera 
Chiasmolithus altus also developed from $\mathrm{Ch}$. modestus, by reduction of its central opening and central cross.

\section{SPECULATION ON THE LINEAGES IN CRUCIPLACOLITHUS}

Perch-Nielsen (1981) suggested that Cruciplacolithus primus developed from Cruciplacolithus inseadus which, in turn, may have developed from the Cretaceous genus. In Zone NP3 (NTp5)Cruciplacolithus subrotundus developed from Criprimus by becoming circular. In Zone NP3 (NTp5) Cr. primus also developed into Cruciplacolithus latipons by an increase in size and an expansion of the axial cross to fill almost the whole central area. In turn, as suggested by Romein (1979) Cr. latipons developed into Clausicoccus spp. by the almost complete disappearance of the axial cross into a perforated or non-perforated central plate, in Zone NP9 (NTp18).

Cruciplacolithus intermedius developed from $\mathrm{Cr}$. primus in Zone NP2 (NTp2) by an increase in size and by the proximal shield and tube cycle becoming more strongly birefringent under cross-polarised light. Cruciplacolithus tenuis developed from $\mathrm{Cr}$. intermedius by the growth of 'feet' at the end of the axial cross, in Zone NP3 (NTp3). Cruciplacolithus frequens developed from $\mathrm{Cr}$. tenuis by anti-clockwise rotation of the central cross in Zone NP3 (NTp5). Campylosphaera eodela developed from $\mathrm{Cr}$. intermedius by an increase in curvature of the shields about the short axis, in Zone NP9 (NTp18). Due to the curvature of the shields, Ca. eodela appears sub-rectangular. In Zone NP10 Campylosphaera dela developed from Ca. eodela by further curving of the shields along the short axis, giving it a rectangular appearance.

In Zone NP9 (NTp18) Cruciplacolithus mutatus developed from $\mathrm{Cr}$. intermedius by becoming sub-circular and by reduction of the axial cross to a more delicate form. The central area in the early form of $\mathrm{Cr}$. mutatus is smaller than in later forms. Cruciplacolithus oulchyensis, in Zone NP12, and Cruciplacolithus staurion, in Zone NP14, developed from $\mathrm{Cr}$. mutatus. The differences are not distinct in these species. Perch-Nielsen
(1971) placed Cr. staurion within Birkelundia because of the possession of a single proximal shield. There is, however, no convincing evidence that this species has a single proximal shield. Cr. staurion shows all the optical characteristics of Cruciplacolithus under cross-polarised light, having a birefringent proximal shield, tube cycle and axial cross, while Birkelundia has a non-birefringent proximal shield.

In Zone NP12 Cruciplacolithus flavius developed from $\mathrm{Cr}$. mutatus by becoming smaller and more elliptical. In turn, Cruciplacolithus cruciatus developed from $\mathrm{Cr}$. flavius by a further reduction in overall size, but with the central opening becoming larger in relation to the width of the shields. In $\mathrm{Cr}$. cruciatus the extremely narrow tube cycle appears serrated under cross-polarised light. In Zone NP12 Cr. flavius also developed into Bramletteius serraculoides by the growth of a paddle-shaped distal process. Within Zone NP21 Cruciplacolithus tarquinius developed from $\mathrm{Cr}$. flavius by the reduction of the central area, whilst in Zone NP22 Cruciplacolithus quader developed from $\mathrm{Cr}$. flavius also by reduction of the central area and by growth of a quadrate distal structure in the centre of the axial cross.

\section{SYSTEMATIC DESCRIPTIONS}

Class Coccolithophyceae Rothmaler, 1951

Order Coccolithales Rood, Hay \& Barnard, 1971

Family Coccolithaceae Kamptner, 1928 emend. Hay \& Mohler, 1967

Genus Sullivania Varol, gen. nov.

Type species. Coccolithus consuetus Bramlette \& Sullivan, 1961. Derivation of name. In honour of Dr F.R. Sullivan, U.S.A.

Diagnosis. An elliptical placolith with a distal shield, a double cycled proximal shield, one distally exposed tube cycle and a central area which is spanned by a diagonal cross.

SEM description. The elliptical placolith consists of a distal shield made up of dextrally imbricated elements and a smaller proximal shield with two cycles. The radial elements of the tube, of which only one cycle is exposed distally, do not

SEM MICROGRAPHS; $\mathrm{Bar}=2 \mu \mathrm{m}$

\section{Explanation of Plate 1}

Fig. 1. Chiasmolithus grandis (From Kapellos \& Schaub, 1973, with permission of the Swiss Geological Society). Distal view, Pyrenees (Southwest France); Fig. 2. Chiasmolithus eograndis; (From Ph.D. collection of Dr M.H. Girgis which is deposited in the University College of London). Proximal view, Middle Eocene (Zones NP15-NP16), Fayum Province, Egypt; Fig. 3.Chiasmolithus sp. (From Ph.D. collection of Dr M.H. Girgis which is deposited in the University College of London). Distal view, Lower Eocene (Zone NP14, lower part) City of Benidorm, Southeast Spain. Fig. 4 Sullivania titus Proximal view, Lower Eocene (Zone NP12), Sile, Istanbul, Turkey; Fig. 5 Sullivania consuetaDistal view, Lower Eocene (Zone NP12), Sile, Turkey.

TERMINOLOGY

a) Distal shield

b) Proximal shield

c) Single/outer tube cycle

d) Inner tube cycle

e) 1st cycle of proximal shield

f) 2nd cycle of proximal shield

g) Proximal lining

h) Tooth

i) Central mesh

j) Distal layer of diagonal central cross (made of longitudinal elements)

k) Diagonal central cross (made of transverse elements)

l) Proximal layer of diagonal central cross (made of transverse elements) 

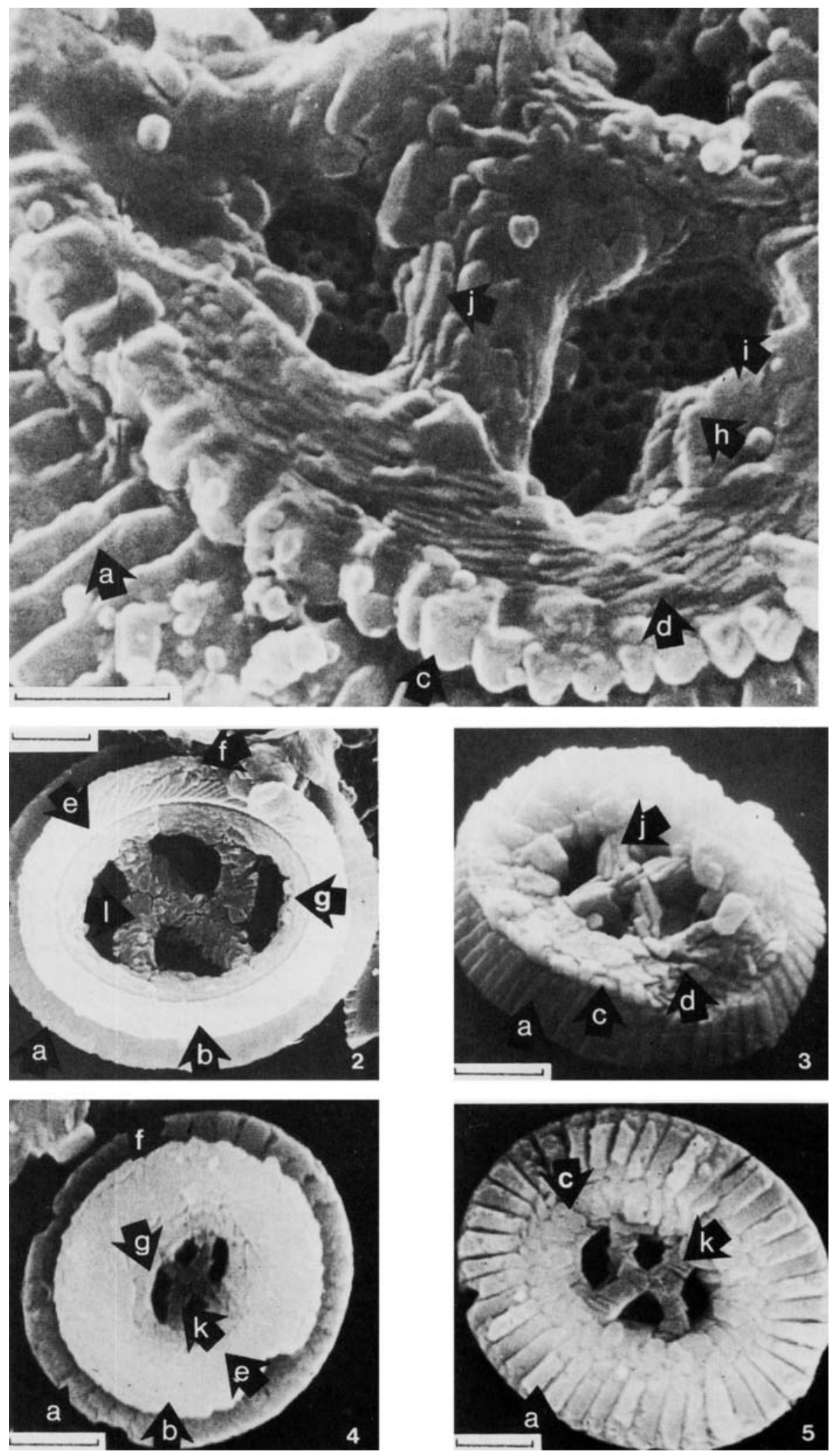


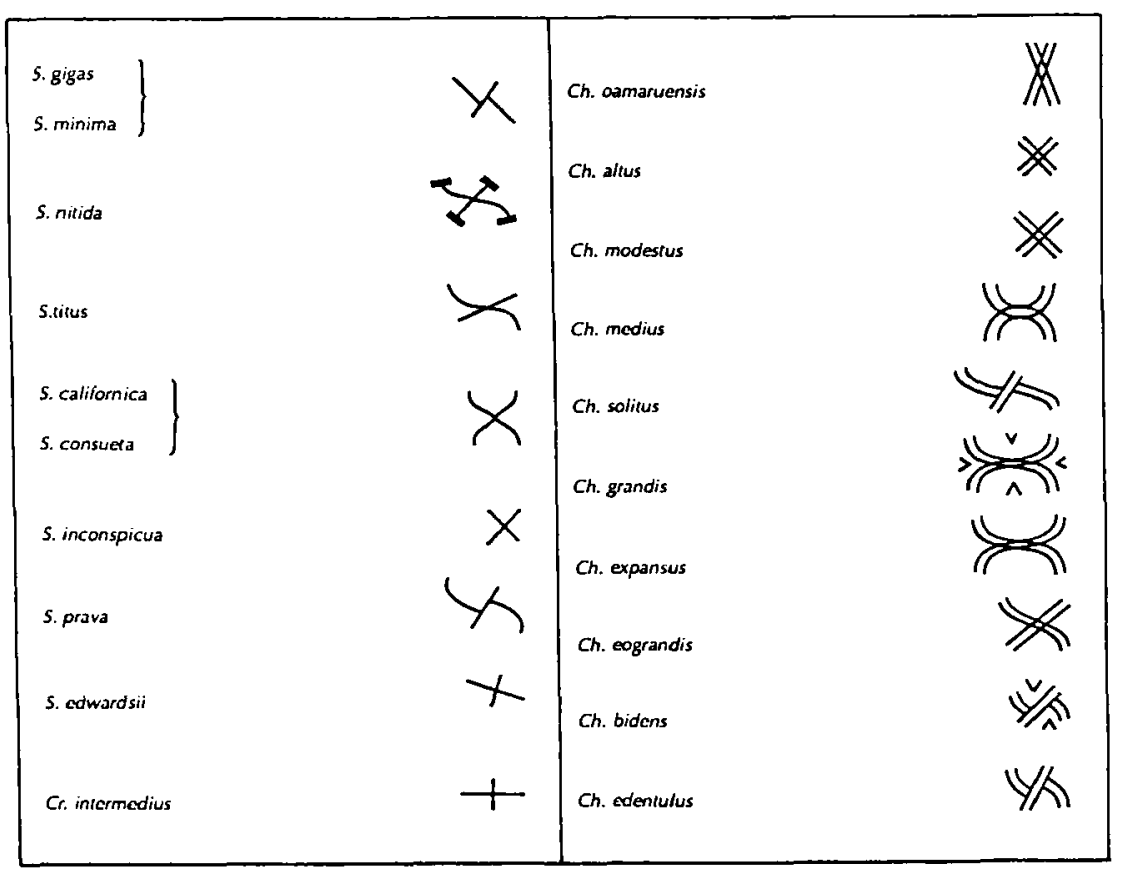

Fig. 3. Characteristics of the central cross in Sulltvania and Chiasmolithus (modified after Perch-Nielsen, 1985).

overlap the inner margin of the distal shield. The central area is spanned by a diagonal cross composed of transverse elements (Fig. 1). So far, no central mesh has been observed in the opening between the arms of the central cross in any species assigned to this genus.

L.M. description. The double cycled proximal shield, the tube (Pl. 1, fig. 5) and the diagonal cross are birefringent whilst the distal shield is non-birefringent under cross-polarised light. The arms of the diagonal cross appear as single units under cross-polarised light.

Remarks. The species of this new genus are distinguished by the shape, angle of rotation and angle between the arms of the diagonal cross, as described by Perch-Nielsen (1985, Fig. 22) and also illustrated here (Fig. 3). The present interpretation is, however, slightly different from that of the former author.

Sullivania differs from Chiasmolithus under the scanning electron microscopeby having a single distally exposed tube cycle, a diagonal central cross in which the arms are constructed of transverse elements, and absence of a central mesh (Fig. 1).Sullivania differs from Chiasmolithus under the light microscope by having a central cross in which the arms appear as a single unit and a strongly birefringent tube cycle without any overlap with the non-birefringent distal shield under cross-polarised light. By contrast in Chiasmolithus the arms of the diagonal cross appear to be divided into two halves longitudinally, and the widebirefringent tube cycles (outer and inner tube cycles cannot be distinguished under the light microscope) overlap the inner margin of the nonbirefringent distal shield.

Sullivania differs from Cruciplacolithus by having a diagonal cross whereas the latter has an axial cross.

Occurrence. The species of this genus occur throughout the world in low and high latitude areas. They become increasingly abundant, however, towards the low latitude areas whereas, conversely, the abundance of Chiasmolithus increases towards the high latitude areas in many studied Eocene sections. The ratio of Sullivania to Chiasmolithus may be a useful guide for the detection of palaeolatitudinal or climatic changes.

In the Eocene sediments of the North Sea area, Irish Sea, North Atlantic, West Africa and Falklands Plateau, species of Chiasmolithus are dominant over Sullivania whilst in the sediments of Turkey, Middle Eastern Countries, India and Pakistan, Sullivania is dominant over Chiasmolithus. In Libya, however, an exceptionally high number of Chiasmolithus was observed in a certain horizon of Eocene age (within Zone NP13) where Sullivania is extremely rare.

Sullivania californica (Sullivan) n.comb. (Pl. 2, fig. 3.)

Basionym:Coccolithus californicus Sullivan, 1964, p.180, P1.2, figs 3-4

\section{Explanation of Plate 2}

\section{ALL CROSS-POLARISED MICROGRAPHS}

Fig. 1. Chiasmolithus oamaruensis. Upper Eocene (Zone NP18), North Sea area (South Viking Graben).

Fig. 2. Sullivania gigas. Middle Eocene (Zone NP15), West Africa DSDP Leg 40, Site 363.

Fig. 3. Sullivania californica. Lower Eocene (Zone NP12), Sile, Turkey

Figs 4-5. Cruciplacolithus prius. Lower Paleocene (Zone NP3/NTp5), Zonguldak, Turkey.

Figs 6-7. Cruciplacolithus intermedius. Lower Paleocene (Zone NP4/NTp6), Zonguldak, Turkey.

Figs 8-10. Sullivania edwardsii. Lower Paleocene (Zone NP4/NTp6), Zonguldak, Turkey.

Fig. 11. Sullivania nitida. Lower Eocene (Zone NP12), Sile, Turkey.

Figs 12-14. Sullivania danica. Lower Paleocene (Zone NP4/NTp7), Zonguldak, Turkey.

Fig. 15. Cruciplacolithus frequens. Lower Paleocene (Zone NP4/NTp8), Zonguldak, Turkey.

Figs 16-19. Cruciplacolithus tenuis. Lower Paleocene (Zone NP4/NTp8), Zonguldak, Turkey.

Fig. 20. Chiasmolithus solitus. Middle Eocene (Zone NP16), North Sea area (South Viking Graben).

Fig. 21. Chiasmolithus altus. Upper Eocene (Zone NP18), North Sea Area (South Viking Graben).

Fig. 22. Chiasmolithus modestus]. Upper Eocene (Zone NP18), North Sea area (South Viking Graben). 

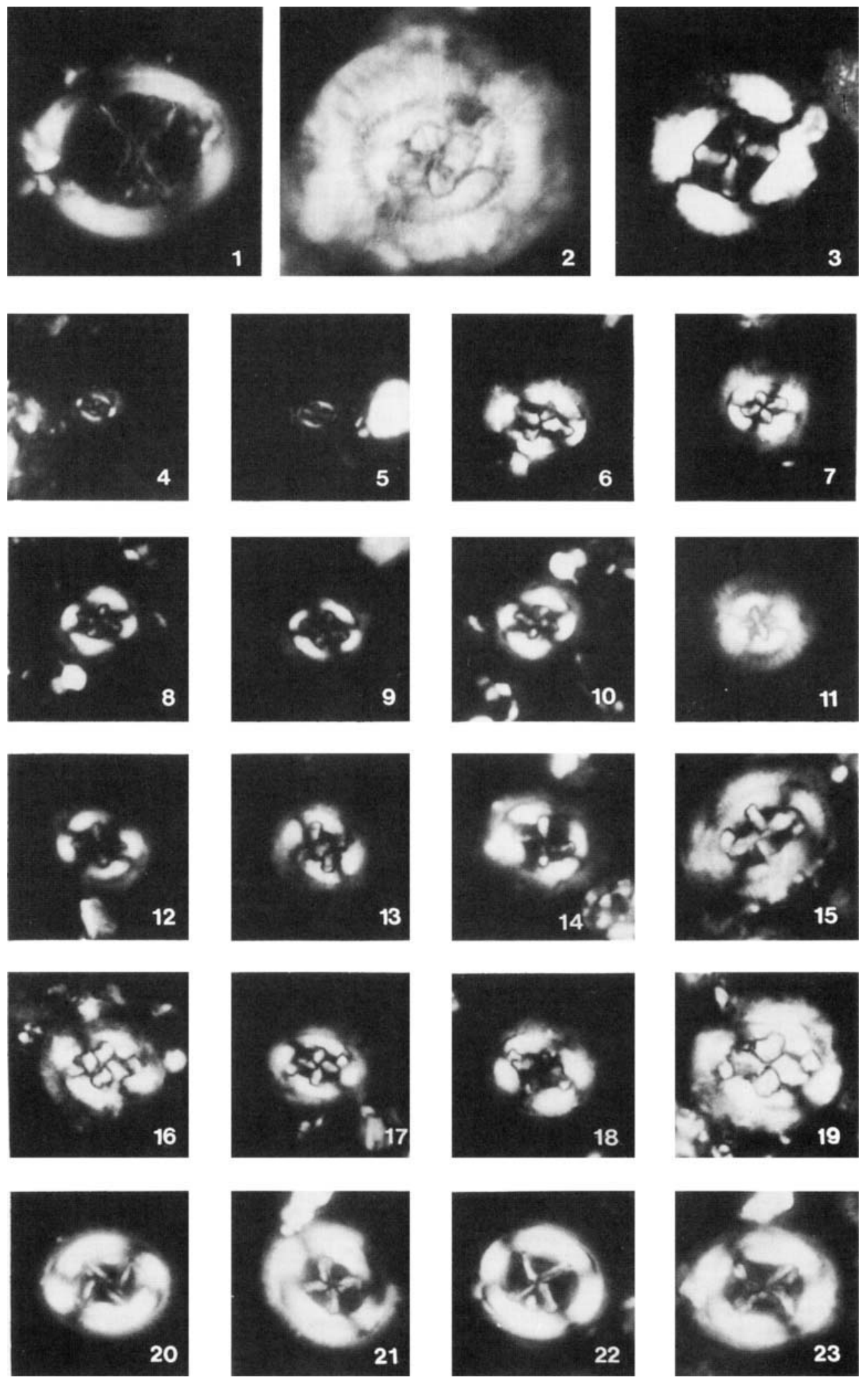
Sullivania consueta (Bramlette \& Sullivan $\mathrm{n}$. comb.) (Pl. 1,fig. 5.)

Basionym: Coccolithus consuetus Bramlette \& Sullivan, 1961, P. 139, Pl. 1, fig. 2.

\section{Sullivania danica (Brotzen ex van Heck \& Perch-Nielsen) n. comb.}

(Pl. 2, figs 12-14)

Basionym: Cribrosphaerella danica Brotzen, 1959, P. 25, fig. 9 (1-8)

-Chiasmolithus danicus Brotzen ex van Heck \& PerchNielsen, 1987, P.280, figs 1-4; Pl. 1, figs 11-26, 33-34.

Remarks. van Heck \& Perch-Nielsen (1987) who designated the lectotype, clearly state that this species has a simple diagonal cross which appears as a single unit under polarised light and their illustration also confirms the statement. In this study, so called 'intermediate' or 'late' forms (Gartner, 1970; Romein, 1979; Perch-Nielsen, 1985 and van Heck \& Prins, 1987) with a complex diagonal cross (appear divided into two halves longitudinally) are excluded from S. danica.

Sullivania edwardsii (Romein) n. comb.

(Pl. 2, figs 8-10)

Basionym: Cruciplacolithus edwardsii Romein, 1979, P. 101, Pl. 2, fig. 7

- Chiasmolithus edwardsii (Romein) van Heck \& Prins, 1987, P. 228-289, Text-fig. 6.

Sullivania gigas (Bramlette \& Sullivan) n. comb. (Pl. 2, fig. 2)

Basionym: Coccolithus gigas Bramlette \& Sullivan 1961, P. 140, Pl. 1, fig. 7

Sullivania inconspicua (van Heck \& Prins) n. comb. Basionym: Chiasmolithus inconspicuus van Heck \& Prins, 1987, P. 289, Pl. 1, figs 11-12, Text-fig. 7.

Sullivania minima (Perch-Nielsen) n. comb. Basionym: Chiasmolithus minimus Perch-Nielsen, 1971, P. 19, Pl. 14, figs 2, 3, 5

\section{Sullivania nitida (Perch-Nielsen) n. comb.}

(Pl. 2, fig. 11)

Basionym: Chiasmolithus nitidus Perch-Nielsen, 1971; P. 20, Pl.13, figs 5-6; Pl60, figs 13-14.

Remarks. At the end of the diagonal cross, 'foot-like' extensions may be confused with an inner tube cycle. However the tube cycle of Chiasmolithus has numerous strongly imbricated elements whereas the 'foot-like' extensions in S. nitida do not number more than eight and do not show any imbrication. Furthermore the 'feet' appear to be part of the diagonal cross, not the tube.

\section{Sullivania titus (Gartner) n. comb.} (Pl. 1, fig. 4)

Basionym: Chiasmolithus titus Gartner, 1970, P. 945, Fig. 17 (1-3)
Genus: Chiasmolithus Hay, Mohler \& Wade (1966) emend. Type species. Tremalithus oamaruensis Deflandre in Deflandre \& Fert, 1954.

SEM description. The elliptical placolith consists of a distal shield, a double cycled proximal shield, double tube cycles, both being exposed distally and a central area occupied by a complex diagonal cross and central mesh. The double cycled proximal shield is smaller than the distal shield which is composed of dextrally imbricated elements. The inner tube cycle is made up of strongly imbricated elements (Pl. 1, fig. 1) but due to diagenetic alteration its elements are usually fused together and appear as a smooth 'blanket' on the outer tube cycle. The overlap of the elements of the inner tube cycle is very strong, appearing as stacks of elements one on top of another in cross section (Pl. 1, fig. 2). The outer tube cycle is made up of radial elements which overlap the inner margin of the distal shield (Pl. 1, figs 1,3). The central cross is distally made up of longitudinal elements, and proximally of transverse elements divided into two halves longitudinally. There are net-like structures in the openings between the arms of the central cross in well preserved specimens (e.g. Pl. 1, fig. 1).

L.M. description. The arms of the diagonal cross are longitudinally divided into two halves under cross-polarised light. The proximal shield and tube cycles are birefringent, while the distal shield and the diagonal cross are non or weakly birefringent, respectively, under cross-polarised light. The tube overlaps the inner margin of the distal shield.

Genus: Cruciplacolithus Hay \& Mohler, 1967. Type Species: Heliorthus tenuis Stradner, 1961.

Cruciplacolithus oulchyensis (Bouche) n. comb. Basionym: Coccolithus oulchyensis Bouche 1962, P. 83, Pl. 1, figs 15-16; Text-figs 4-5

\section{ACKNOWLEDGEMENTS}

I would like to thank Dr K.A. von Salis Perch-Nielsen, Dr M.H. Girgis, Mr D.J. Harrison, Miss S.E. van Heck and especially Mr B. Prins for their constructive criticism. I also thank Dr C. Kapellos and the Swiss Geological Society for letting me photographically reproduce Pl. 1, Fig. 1 from Kapellos \& Schaub (1973). Figures 2 and 3 in Plate 1 are kindly provided by $\mathrm{Dr}$ M.H. Girgis. The micrographs were printed by $\mathrm{Mr} \mathrm{J}$. Davey, University College, London, whose help is much appreciated.

Manuscript received March 1991

Revised Manuscript accepted June 1992

\section{REFERENCES}

Bouché, P.M. 1962. Nannofossiles calcaires du Lutétien du bassin de Paris. Rev. Micropaléont., 5(2), 75-103.

Bramlette, M.N. \& Sullivan, F.R. 1961. Coccolithophorids and related nannoplankton of the Early Tertiary in California. Micropaleontology, 7, 129-174.

Brotzen, F. 1959. On Tylocidaris species (Echinoidea) and the stratigraphy of the Danian of Sweden. Arsbok. Sver. Geol. Unders., 54(2), 1-81.

Deflandre, G. \& Fert, C. 1954. Observations sur les Coccolithophoridés actuels et fossiles en microscopie ordinaire et éléctronique. Amm. Paleontol., 40, 115-176. 
Hay, W.W. \& Mohler, H.P. 1967. Calcareous nannoplankton from Early Tertiary rocks at Pont Labau, France, and Palaeocene-Early Eocene correlations. Journ. Paleont., 41, 1505-1541.

Hay, W.W., Mohler, H.P. \& Wade, M.E. 1966. Calcareous nannofossils from Nal'chik (northwest Caucasus). Eclogae Geol. Helv., 59, 379-99.

Heck, S.E. van \& Perch-Nielsen, K. 1987. Validation of Chiasmolithus danicus. Abh. Geol. B.-A., 39, 279-283.

Heck, S.E. van \& Prins, B. 1987. A refined Nannoplankton zonation for the Danian of the Central North Sea. Abh. Geol. B.-A., 39, 285-303.

Kamptner, E. 1928. Über das system und die phylogenie der Kalkflagellaten. Arch. Protistenk, 64, 19-43.

Kapellos, C. \& Schaub, H. 1973. Zur Korrelation von Biozonierungen mit Grossforaminiferen und Nannoplankton im Paläogen der Pyrenäen. Eclogae Geol. Helv., 66(3), 687-737/

Martini, E. 1971. Standard Tertiary and Quaternary calcareous nannoplankton zonation. Proc. II Plankt. Conf. Rome, 1970, 2, 739 777.

Perch-Nielsen, K. 1971. Elektronenmikroskopische Untersuchungen an Coccolithen und verwandten Formen aus dem Eozan von Danemark. Det Kongelige Danske Videnskabernes Selskab Biol.Skrifter, 18(3), 1-76.

Perch-Nielsen, K. 1979. Calcareous nannofossil zonation at the Creta-
ceous/Tertiary boundary in Denmark. In: Birklund, T. \& Bromley, R.G. (eds). Cretaceous/Tertiary boundary event-symposium. I. The Maastrichtian and Danian of Denmark, 115-135.

Perch-Nielsen, K. 1981. Les coccolithes du Paléocéne pres de El Kef, Tunisie et leurs ancêtres. Cah. Micropaleontol., 1981 (3), 7-23.

Perch-Nielsen, K. 1985. Cenozoic calcareous nannofossils. In: Bolli, H.M., Saunders, J.B. and Perch-Nielsen, K. (eds). Plankton stratigraphy, Cambridge University Press, Cambridge, 422-454.

Rood, A.P., Hay, W.W. \& Barnard, T. 1971. Electron microscope studies of Oxford Clay coccoliths. Eclog. Geol. Helv., 64(2), 245-272.

Rothmaler, W. 1951. Die abteilungen und klassen der pflanzen. Report sp. nov., 54, 256-266.

Romein, A.J.T. 1979. Lineages in Early Paleogene calcareous nannoplankton. Utrecht Micropaleontol. Bull., 22, 1-231.

Stradner, H. 1961. Vorkommen von Nannofossilien in Mesozoicum und Alttertiar. Erdoel Zeitschr., 77, 77-88.

Sullivan, F.R. 1964. Lower Tertiary nannoplankton from the California Coast ranges. I. Paleocene. Univ. Calif. Publ. Geol. Sci., 44, 163227.

Varol, O. 1989. Palaeocene calcareous nannofossil biostratigraphy. In: Crux, J.A. \& Heck, S.E. van (eds), Nannofossils and their applications. Ellis Horwood, Chichester, 265-310. 